\title{
Modernise it, sustainabilise it! Swiss energy policy on the eve of electricity market liberalisation
}

\author{
Maya Jegen ${ }^{\mathrm{a}, *}$, Rolf Wüstenhagen ${ }^{\mathrm{b}, 1}$ \\ ${ }^{\mathrm{a}}$ Université de Genève, Département de Science Politique, Uni Mail, Bd du Pont d'Arve 40 CH-1211 Genève 4, Switzerland \\ ${ }^{\mathrm{b}}$ Universität St. Gallen, Institut für Wirtschaft und Ökologie (IWÖ-HSG), Tigerbergstrasse 2, CH-9000 St. Gallen, Switzerland
}

Received 6 December 1999

\begin{abstract}
In Switzerland like in many other countries, political decision makers face the two-fold challenge to adapt current electricity market regulation to achieve different goals at the same time: market liberalisation and sustainable development. The general trend of the liberalisation of the electricity markets implies radical structural changes of the electricity industry as well as of the institutional rules for its regulation. But how can the overall goal of sustainable development be brought in line with the ongoing discussion on market (de)regulation? After reflecting on the objectives of the liberalisation process, we analyse the political acceptance of different instruments to achieve environmental goals in a liberalised electricity market; the analysis is based on empirical data from an inquiry among 250 key players of Swiss energy policy. We compare these outcomes to theoretical (economic) insights on 'first-best', 'second-best' and 'third-best' solutions, and we conclude with a closer look at perspectives for a future energy supply structure in Switzerland. (C) 2000 Elsevier Science Ltd. All rights reserved.
\end{abstract}

Keywords: Liberalisation of the electricity market; Sustainable development

\section{Introduction}

Like many other countries, Switzerland has signed the Kyoto agreement on climate protection and the government has committed itself to a policy of sustainable development. At the same time, Switzerland is on the edge of liberalising its electricity market. Given these two recent developments, the need to embark on a sustainable energy policy is accompanied by the need to adapt and modernise existing rules to the new market structures. In this paper, we will evaluate the prospects for Swiss energy policy to meet this double challenge, based on an empirical survey among 250 key players in Swiss energy policy. We will first report on the methodology of this survey and give a short overview of the structure of the Swiss electricity supply system. Then different parts of the survey results are presented, namely the energy policy makers' views

\footnotetext{
*Corresponding author. Tel.: + +41-22-705-8375; fax: ++41 22-705-8364.

${ }^{1} \mathrm{http}: / /$ www.iwoe.unisg.ch/institut/rwu.htm

E-mail addresses: maya.jegen@politic.unige.ch (M. Jegen), rolf. wuestenhagen@unisg.ch (R. Wüstenhagen).
}

- on motivations for market liberalisation,

- on the impact of market liberalisation on the environment,

- on elements of a mix for re-regulation of the electricity sector (including energy taxes, subsidies, and ecolabelling), and finally

- on long-term perspectives of the Swiss energy sector.

In other words, on the basis of a descriptive analysis we present a kind of state of mind of how the central political actors in Swiss energy policy think about key issues of market liberalisation and sustainable development.

\section{About the data}

Our data ${ }^{2}$ reflects evaluations of energy policy topics by 250 key players, i.e. answers to a face-to-face interview

\footnotetext{
${ }^{2}$ The data was collected for a research project on energy policy in the context of the Priority Program Environment of the Swiss National Science Foundation.
} 
based on a standardised questionnaire. Accordingly, we do not attempt to resituate complete chains of arguments, but try to give an idea of the current trends of expressed opinions. (It is obvious that this implies no absolute causal correspondence between the key players' statements and their effective decision-making behaviour). The key players have been interviewed during summer 1998, which entails also that the questions referred to the state of the debate of that time; this precision is important with respect to the changing salience of certain liberalisation issues as well as to the complex debate on taxes.

But who are these key players? This energy policy elite is defined as all principal actors - exponents from political parties, trade unions, business, utilities, scientific community, public administration, NGOs - who participate directly or indirectly in the political decision-making process (Kriesi, 1980). Because their political participation is not confined to a particular arena (e.g. Parliament) and because national as well as actors from six selected cantons are included, the key players may be considered as members of advocacy coalitions within the energy policy domain (e.g. Sabatier and Jenkins-Smith, 1993). ${ }^{3}$ However, our attempt here is not to closely examine the belief systems of the advocacy coalitions and we limit our presentation to a descriptive analysis of the data. Thus, if referred to, the advocacy coalitions mirror roughly the division between right- and left-wing forces, or correspondingly Scharpf's (1997) "pro-growth" and "pro-ecology" coalitions.

The identification of the actors was based on the reputational, positional and decisional approaches (Birnbaum, 1973, Dahl, 1961, Kriesi, 1980). The latter, which identifies the actors who participated in the decisionmaking of selected energy policy issues, was not applied on the cantonal level. ${ }^{4}$ The combination of these three approaches generated more than 1000 actors as well as information about their political and professional positions, frequency of participation, membership in associations and managing boards, representation of (energy) capital, etc. Different criteria (e.g. minimal frequency of participation, minimal amount of represented capital) were defined and a final number of 300 actors selected.

\footnotetext{
${ }^{3}$ Following the Advocacy Coalition Framework (ACF), two or more advocacy coalitions are formed around specific belief systems in a policy domain, i.e. the members of a coalition share key values and principal policy ideas and try to impose them in the political process. In this "competition of belief systems" social learning may occur on minor aspects, but radical changes of the political orientation and of the power monopoly are mostly due to external shocks. Empirically, advocacy coalitions are observable within a decade or more.

${ }^{4}$ On the national level the 12 most important legislative issues of the last 10 years were selected. The omission of the decisional approach on the cantonal level is mainly due to difficulties in comparing cantonal legislations.
}

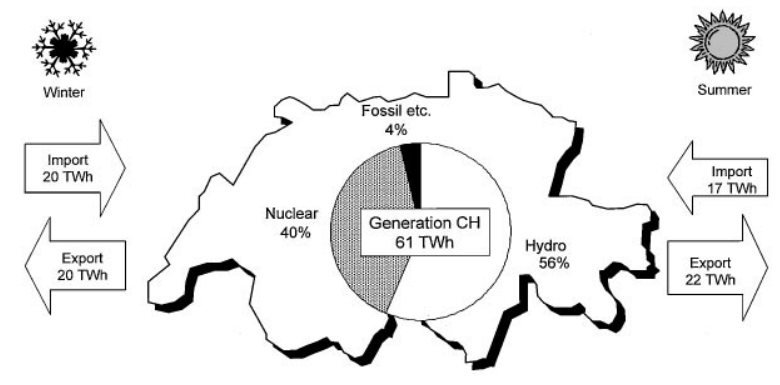

Fig. 1. Electricity generation in Switzerland (1998). (Source: Wüstenhagen, 2000)

About $80 \%$ of the contacted actors were willing to participate in an interview. ${ }^{5}$

On specific issues, theses data are compared to data from a survey among green electricity providers. ${ }^{6}$ All, at that time namely 23 suppliers of green electricity in Switzerland were contacted in a written survey in August 1998. Twenty-one out of 23 utilities, which are usually municipal or local electric utilities, responded to the questionnaire. Even though the sample is rather small, it quite completely reproduces the entirety of the Swiss green electricity suppliers. The respondents are heads of marketing departments, project leaders of green electricity or managing directors of (smaller) utilities.

\section{About the Swiss energy system}

Fig. 1 gives an overview on today's electricity supply system in Switzerland. The major sources for electricity generation are hydropower plants $(56 \%)$ and nuclear power plants $(40 \%){ }^{7}$ Only $4 \%$ are generated by other sources, mainly fossil fuels and to a smaller part waste incineration and new renewables. Thus, the $\mathrm{CO}_{2}$ intensity of electricity generation in Switzerland is extremely low. However, Switzerland is a major centre for European electricity trading, which means that there is extensive electricity imports and exports - in the order of magnitude of $20 \mathrm{TWh}$ both in winter and in summer, compared to about $61 \mathrm{TWh}$ domestic generation. Taking these international aspects into account, the greenhouse gas emissions associated to electricity consumed in Switzerland might be somewhat higher than what an isolated view on the Swiss electricity supply system suggests. Another aspect that puts the low $\mathrm{CO}_{2}$ intensity into perspective is that electricity accounts for only $\frac{1}{5}$ of final

\footnotetext{
${ }^{5}$ The number of 300 actors was fixed in advance by budget limits and interview techniques. For ampler details on the selection of actors and the collection of data, cf. Jegen (1999).

${ }^{6}$ For more details on the results of this survey, cf. Wüstenhagen (1998).

${ }^{7}$ Data according to VSE (1999).
} 
energy use in Switzerland, the rest being heating and transportation, both strongly dominated by fossil fuels.

As far as perspectives of the future development of Swiss electricity supply are concerned, hydropower capacities - due to natural and social constraints - can hardly be extended. On the other hand, about half of the population is opposed to nuclear energy. Following the acceptance of a popular initiative, a 10-year nuclear moratorium took effect in 1990, fairly paralysing the nuclear legislation since. Furthermore, Swiss nuclear energy may be exposed to economic difficulties in a liberalised market because of its high generation costs (stranded investments). Alternatively, an increase in fossil-fuelbased power generation will have difficulties in terms of public acceptance because of its greenhouse gas emissions. ${ }^{8}$ Against the background of the actual power supply and the political situation, instruments promoting energy efficiency as well as an accelerated and large diffusion of new renewable energy sources can be considered as the (constitutionally fixed) cornerstones of a future sustainable energy policy in Switzerland. As for the market structure, Switzerland as a non-EU member did not yet have to open its electricity market. More than 900 electric utilities still operate in monopolistic regional markets. ${ }^{9}$ However, a bill on the electricity market is on the political agenda for nearly 2 years now and expected to come into force in 2001. Starting with large industrial consumers and then gradually opening the market down to the household level within 6 years, customers would have the opportunity to choose their electricity provider. Even before the actual liberalisation of the market, utilities are starting to commit themselves to more customer orientation, including price reductions for large customers and product differentiation with green marketing programmes. Given the requirements of market liberalisation and sustainable development, decision-makers face the challenge of designing a policy mix that is compatible with the objectives of both developments and that, at the same time, is politically consensual. As experiences of other liberalised industries such as financial markets or telecommunications and the liberalisation of the electricity sector in other countries make clear, liberalisation implies always a re-regulation and there are different ways to re-regulate (Vogel, 1998). Thus, even though the liberalisation is of concern and has major consequences for the (private) industry sector, political

\footnotetext{
${ }^{8}$ These difficulties also apply to combined heat and power generation (CHP), although compared to the present situation of $\mathrm{CO}_{2}$-low electricity generation but inefficient, fossil-based space heating, $\mathrm{CHP}$ could often be the preferred choice from an environmental point of view.

${ }^{9}$ While especially the municipal and communal utilities have traditionally been restricted to their local supply areas, it has to be noted, however, that some of the major utilities (especially the six Überlan$d$ werke) have a strong tradition in cross-border trading.
}

regulation remains nonetheless crucial. With regard to environmental issues this means that solutions should be considered equally from the economic and the regulatory perspective.

\section{Why electricity market liberalisation at all?}

Although market liberalisation seems to be en vogue as a global trend, entailing a fundamental restructuring of the electricity market, it seems legitimate to reflect on the expected goals of this process. According to Drillisch and Riechmann (1998, p. ix), the primary goal of restructuring policies is to increase (economic) efficiency within the electricity industry. They point out, however, that other policy goals like environmental protection or the provision of security of supply have to be taken into account likewise when designing reform policies. After all, the choice of a market model depends on the assessment of each of these goals within a policy design.

In our empirical survey, we have asked the Swiss decision-makers about the relative importance of different motivations for restructuring. As Table 1 shows - somewhat surprisingly — the most important motive is not economic efficiency, but compliance with EU regulation. Eighty-five per cent of the interviewed agree that ensuring compatibility with the European Union is a rather important or very important motivation for liberalisation of the Swiss electricity market. This almost unanimous perception reflects daily routine of Swiss politics: The country does not participate in the decisionmaking process of the European Union, but has, nevertheless, to comply to its regulation due to the close intertwining of the economies. Even if this closeness may be stronger in the electricity sector than in other industries, the "europhil" adjustment of the legislation corresponds to a general trend. Whereas the Swiss export trade has always been orientated to the world markets (Katzenstein, 1985), the domestic markets used to be protected by the national legislation and were often subsidised. However, as Mach (1998) points out, the neoliberal turn puts an end to this protective tradition and puts these markets under pressure.

Apart from the question about EU compatibility, we asked three more questions about motives driving the liberalisation. Seventy-two per cent of the interviewees agree on a general level that overcoming inefficiencies of the existing monopolistic market structure is rather important or very important. However, there is a minority of exponents denying the existence of such inefficiencies; among them about half of the electric utility representatives. A considerable number of exponents of the electricity sector seem to consider liberalisation as an unnecessary exercise intervening to their already efficient business routines. Since price reduction could be an outcome of an increase in efficiency, we asked for the relative 
Table 1

Evaluation of motives driving the market liberalisation ${ }^{\mathrm{a}}$

\begin{tabular}{|c|c|c|c|c|}
\hline & Compatibility with EU & Monopoly inefficiency & Price reduction for industry & Price reduction for all \\
\hline Very important & $45 \%$ & $40 \%$ & $38 \%$ & $19 \%$ \\
\hline Rather important & $40 \%$ & $32 \%$ & $30 \%$ & $28 \%$ \\
\hline Rather unimportant & $11 \%$ & $20 \%$ & $23 \%$ & $39 \%$ \\
\hline Very unimportant & $4 \%$ & $7 \%$ & $9 \%$ & $15 \%$ \\
\hline $\mathrm{N}$ & 236 & 230 & 235 & 231 \\
\hline
\end{tabular}

a"How important are the following reasons for the liberalisation of the electricity market?".

importance that is assigned to price reduction for two different customer groups: industrial customers and all customers. While $68 \%$ agree that price reduction for industry is an important motive for liberalisation, a majority of $54 \%$ agree, on the contrary, that price reduction for all customers is not a major concern in the liberalisation process. This reflects perfectly the commonplace that the industrial price level in Switzerland is comparatively high and that a globally competing industry needs support in its struggle of reducing costs. By contrast, electricity charges for Swiss households are already low compared to other countries. It should be noted, however, that such price comparisons are always arbitrary to some extent, and that there is an element of allocative shift in such a set of goals that is hardly straightforwardly discussed and might cause resistance when being set on the political agenda ("the small consumers have to pay the bill"). There is another way of looking at the relative lower importance of price reduction for all customers: it might indicate a certain scope for the achievement of other policy goals within a liberalised market. For example, thanks to efficiency gains cost reductions might be compensated by the introduction of environmental taxes to internalise external costs.

When looking at the answers at a less aggregate level it turns out that especially among the leftist and green parties, there is a common assent that price reductions are not the core issue. Particularly, the green representatives show a very consistent attitude towards price: $85 \%$ consider low prices for industry, even $95 \%$ low prices for everybody, as unimportant. This is not surprising, as lower prices tend to lead to higher energy consumption and thus increase the negative environmental impacts. The social democrats' answers are less consistent: whereas $65 \%$ esteem lower prices for everybody as unimportant, a strong minority of $49 \%$ think that they are important for industry. This might reflect an conflict between the goals of environmental protection and job security, which are traditionally perceived as having to be traded off against each other. It differs from what would usually be expected from a left-wing party, which is to promote purchasing power for the "small people" and being rather opposed to industry interests. On the other hand, one may argue that the social democrats worry about the considerable number of jobs jeopardised in the restructuring process of the electricity industry. One of the reasons for inefficiencies in the actual monopoly of the electricity sector is its relatively high job intensity (or bureaucratic kind of organisation). Therefore, reducing labour cost will probably be high on the agenda of a more profit-oriented management. Less pressure on prices might then mean a "smoother" restructuring with less job losses. Quite as expected, the issue of cost gets high priorities on the right-centre-wing side: $87 \%$ consider a low price for industry and $58 \%$ a low price for all consumers as important.

\section{Will the liberalised market result in environmental improvements?}

To find out whether the key players in Swiss energy policy perceive a need for a specific regulation to achieve environmental goals, we have asked whether they expect market liberalisation to result in the achievement of two important environmental goals: the stabilisation of the electricity consumption and the promotion of renewable energy. As shown in Table 2, the result is pretty explicit. eighty-six per cent of the interviewed do not expect the market liberalisation to result in an (automatic) stabilisation of the electricity consumption, whereas even more do not expect a promotion of renewable energies as a direct outcome of the restructuring process $(89 \%)$. Thus, the empirical data show that the majority of Swiss energy key players see an inherent danger of not achieving environmental goals in the process of market liberalisation, i.e. in an autoregulated market.

On the other hand, the market may offer new opportunities. An argument is that a latent demand for green electricity is going to be released within a liberalised market. Environmentally oriented customers are no longer forced to buy a uniform electricity mix from their incumbent utility but are free to choose more sustainable products from green electricity marketers. Therefore, the high appreciation of these technologies - mainly among private customers - might be transformed into actual market shares.

We have asked the interviewees two questions about their estimation of green electricity marketing: whether it 
Table 2

Stabilisation of electricity consumption and promotion of renewable energy in the liberalised market ${ }^{\mathrm{a}}$

\begin{tabular}{lcc}
\hline & $\begin{array}{l}\text { Stabilisation of power } \\
\text { consumption }\end{array}$ & $\begin{array}{l}\text { Promotion of renewable } \\
\text { energy }\end{array}$ \\
\hline Absolutely & $4 \%$ & $3 \%$ \\
Rather & $10 \%$ & $8 \%$ \\
Rather not & $48 \%$ & $53 \%$ \\
Not at all & $38 \%$ & $36 \%$ \\
N & 218 & 228 \\
\hline
\end{tabular}

a"Is the objective of stabilising the electricity consumption guaranteed by the liberalisation of the electricity market?". "Is the objective of promoting renewable energies guaranteed by the liberalisation of the electricity market?".

Table 3

Green electricity marketing in the liberalised market ${ }^{\mathrm{a}}$

$\begin{array}{ll}\begin{array}{l}\text { Marketing for } \\ \text { renewable energy }\end{array} & \begin{array}{l}\text { Marketing as a substitute } \\ \text { for other energy policy } \\ \text { instruments }\end{array}\end{array}$

\begin{tabular}{lcc}
\hline Absolutely & $32 \%$ & $13 \%$ \\
Rather & $49 \%$ & $17 \%$ \\
Rather not & $15 \%$ & $29 \%$ \\
Not at all & $4 \%$ & $42 \%$ \\
N & 234 & 224 \\
\hline
\end{tabular}

a "Can a clever marketing increase the demand for green electricity?". "Does the introduction of a green electricity offer make unnecessary other instruments promoting renewable energies?".

is able to increase the market share of renewables, and whether it substitutes for other energy policy instruments promoting renewables. The result is evident: There is a large consensus that green electricity marketing can contribute to the promotion of renewable energy $(81 \%)$, but that it is certainly not a substitute for other energy policy measures $(71 \%)$ (Table 3$)$.

This latter result is well in line with another survey among utilities offering green electricity. ${ }^{10}$ From the 23 green electricity providers questioned, 18 utilities gave a feedback on that issue and their statements are fairly close to those of the decision-makers, with again a significant majority $(61 \%)$ answering in the negative.

As Fig. 2 shows, the utilities advocate the need for additional energy policy measures to promote renewables to a slightly lower extent than the 224 energy policy key players. At first sight, this might be seen as the result of their self-confidence as successful marketers.

\footnotetext{
${ }^{10}$ There was no overlap between the two samples, which can be explained by the fact that green electricity is a new phenomenon for the industry. The green electricity marketing managers are often younger utility people, whereas the selection criteria for the 250 key players required a longer-term involvement into the energy policy debate.
}

Energy policy key players

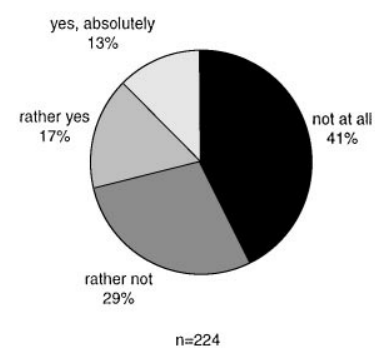

Green Electricity Providers (18 Swiss Utilities)

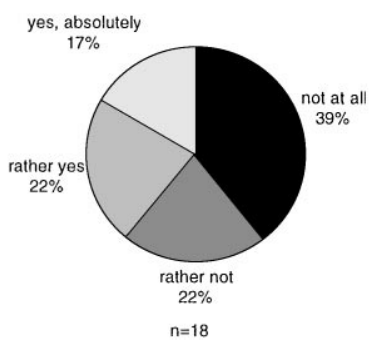

Fig. 2. Green electricity marketing is not considered as a substitute for energy policy instruments. Does green electricity marketing substitute for other energy policy instruments to promote renewable energies? (Source: Wüstenhagen, 2000)

A more detailed analysis suggests, however, a different interpretation. The subdivision of the 18 utilities into two equal groups by their market share on green electricity programs ${ }^{11}$ shows that especially the market leaders feel the need for additional policy measures ( $78 \%$ answered "no, not at all" or "no, rather not"). By contrast, the least successful laggards do consider their marketing activities as a substitute for further energy policy measures promoting renewable energy (55\% "yes, absolutely" or "rather yes"). This seemingly paradoxical result might indicate that there are a number of utilities that have a defensive motivation to promote green electricity and are generally sceptical towards renewable energies. ${ }^{12}$

As can be concluded from these data, green electricity marketing may contribute to, but will not be sufficient on its own to achieve environmental goals in the process of market liberalisation. Hence there is an evident need for further policy measures.

\section{Designing an intelligent mix for re-regulation}

Given the high priority of economic efficiency among the goals of market liberalisation, environmental objectives should also be achieved in an efficient way. Economic theory suggests the internalisation of external costs as the optimal solution, which can be attained by energy or emission taxes. In fact, such taxes have been under debate in Switzerland for a long time. During the 1980s, the Swiss Parliament deliberated repeatedly on a constitutional article of energy policy. This article was finally accepted in 1989, but only because the controversial

\footnotetext{
11 "Market share" means the percentage of household in the corresponding supply area who have ordered some green electricity from their utility.

${ }^{12}$ Due to the small sample, these results have to be interpreted with care. However, the 18 respondents represent almost all utilities offering green electricity in Switzerland today.
} 
issue, the energy tax, was cancelled. Likewise the bill on $\mathrm{CO}_{2}$ reduction was disputed at great length because of the emission taxes. The current version of the bill relies on subsidiary and voluntary measures, which means that the political power players have postponed an ecologically effective tax. In 1995 environmental NGOs submitted two popular initiatives demanding the introduction of energy taxes. The issues should be submitted to the popular vote in September 2000. The Parliament has elaborated a counterproposal to the two initiatives, proposing a more moderate taxation level. Thus, compared to the 1980s, energy taxes as well as an ecological tax reform have become a central issue on the political agenda in the late 1990s, which points to the fact that this issue, originally supported by the left-green wing, has now found its supporters across the parties. There is, however, still considerable resistance against energy taxes as a closer look at our data shows.

The interviewed key players were asked to evaluate a number of energy policy instruments by a set of criteria including their influence on economic competition, their ecological efficiency and the scope for political consensus and wide-spread implementation. Among these instruments, we asked about a tax on $\mathrm{CO}_{2}$ emissions, a tax on non-renewable energy and a tax on the energetic quality of buildings. In their overall evaluation, all three taxes are ranking behind voluntary instruments, such as energy-specific building standards of the Swiss Association of Engineers and Architects (SIA 380/1), environmental management systems according to ISO 14001 or MINERGIE, a Swiss label for energy-efficient buildings and products. These voluntary instruments are positively evaluated with respect to their suitability for political consensus and, at a lesser degree, for practical execution. However, they fail to satisfy the criterion of ecological efficiency. By way of contrast, incentive taxes rank higher in ecological terms, but cannot compete as to the criteria of political consensus and implementation (Jegen and Kriesi, 1999). This outcome reflects what we mentioned above; namely that legislating on taxes still is a lengthy and controversial process in Switzerland. But we can also deduce that political decision-makers are well aware that taxation is the most effective way to achieve environmental goals, even though they still prefer less effective, but more popular instruments - even if this eventually means that energy policy may fail to achieve environmental goals.

While the number of fundamental opponents of energy and emission taxes seems to be small, a strong minority opposes more subtly. One of its main arguments is that such taxes must be introduced in an internationally harmonised manner in order to protect domestic industries against disadvantages in international competition (for similar arguments in other European countries, cf. Schlegelmilch, 1998, p. 18). Another issue is the actual tax level. After a tenacious debate the Swiss Parliament agreed finally on $0.3 \mathrm{Rp} . / \mathrm{kWh}$. This is not only substantially less than what has recently come into effect in other countries like Germany, but also far below a full internalisation of external costs. ${ }^{13}$ If any proposal significantly closer to the full cost internalisation - and hence a "first best" solution to achieve environmental goal - should find a majority within the next years, decisive opinion changes among the decision-makers are required.

As follows from our data, this kind of rethinking would particularly be necessary among right-centre exponents; the left-green wing and environmentalists already support - distinctly above average - the economic "first best" solution. However, the change of mind concerns not only energy policy key players, but also public opinion to a large extent. Within a system of direct democracy, which demands a sanctional vote of the people, the acceptance of energy taxes or an ecological tax reform by a majority of citizens is crucial. Regarding the ecological tax reform (ETR), Kriesi (1999, p. 11) concludes from a panel study that the fraction of the population which is in favour of the reform is increasing and that there is a genuine chance of acceptance. In order to form and maintain a majority, persuasion should particularly be applied to the number of voters who are more or less concerned by the quality of environment, but do not have a strong opinion yet on this new and complex instrument. In analogy with the key players' survey Kriesi sees a potential for persuasion among the right-centre voters and among the French-speaking Swiss. As to the latter he presumes that they are less informed by their media and by their political elite. Furthermore, the author notices that for citizens who have not definitively formed their opinion yet cost-benefit considerations are quite important. This indicates also that the acceptance of a tax reform depends considerably on the mode of redistribution and on its fiscal neutrality. Likewise, the importance of this neutrality is emphasised by Schlegelmilch (1998, p. 12) concerning the ETR in the EU and in Germany in particular: "It is crucial that it [ETR] is designed revenue-neutral as this is a prerequisite to ensure confidence in the reform." The German example illustrates as well the importance of cost-benefit considerations: the proposal of the Green Party to increase the price of gasoline to $5 \mathrm{DEM} / 1$ provoked a wave of indignation. Whether from a "bottom up" or from a "top down" perspective, the "first best" solution still runs against various resistance and the basic acceptance of increased energy taxation is obviously not translated into a full external cost internalisation in the near future. Together with problems in identification and monetarisation of "real" external costs, the political difficulties in the decision-making process of

\footnotetext{
${ }^{13}$ This is particularly true if we consider that scientific studies on external costs cannot fully account for uncertain future events like risks associated to climate change or nuclear waste disposal.
} 
Table 4

Effectiveness of instruments for achieving environmental goals in the liberalised market

\begin{tabular}{lcc}
\hline & $\begin{array}{l}\text { Subsidies for } \\
\text { renewable energy }\end{array}$ & Prioritising hydropower \\
\hline Absolutely & $26 \%$ & $24 \%$ \\
Rather & $44 \%$ & $25 \%$ \\
Rather not & $15 \%$ & $24 \%$ \\
Not at all & $15 \%$ & $26 \%$ \\
N & 227 & 221 \\
\hline
\end{tabular}

energy taxes point out the need to put "second best" solutions in place, such as subsidies for renewables or the creation of a separate market for renewables (Drillisch and Riechmann, 1998, p. 27). When evaluating the key players' opinions on these second best instruments, it has to be noted that the debate in Switzerland is not very mature yet. Thus, many of the interviewees may have referred to basic assumptions, but may be lacking sophisticated mental models about the concrete implementation of such instruments. The details of implementation do, however, have a significant impact on their efficiency. Given these limitations, we will report on the data gathered from our survey on these issues.

The policy makers have been asked whether they believe that subsidies could contribute to promoting renewables. The results are shown in the first column of Table 4 disregarding whether they would support them or not, $70 \%$ think that subsidies might be effective for that purpose. Economic research shows that such subsidies can also be efficient, if correctly implemented. Drillisch and Riechmann suggest not paying investment subsidies but binding the payments to the output of renewable power plants. This guarantees that the investor has an incentive to maximise the output of his plant and the subsidy provider does not have to carry the technical risk (e.g. of production failures). They further recommend tying the amount of the subsidy to the market price, i.e. pay a fixed per $\mathrm{kWh}$ premium on top of the market price. This mechanism comes closest to a "first best" emission tax (Drillisch and Riechmann, 1998, p. 45).

One of the instruments qualified as "third best" by Drillisch and Riechmann (1998, p. 47) is the artificial segmentation of the generation market into a segment of renewable technologies and a segment of traditional generation. While this was originally conceived for the development of new renewable generation capacity, it has been suggested to introduce a similar regulation for hydropower on the Swiss market. The rationale for this is the assumption that some hydropower plants have production costs that may not be competitive in a liberalised market, i.e. the need for protecting this renewable domestic energy source.

The opinion of the interviewed Swiss energy politicians is quite diverging on this issue - $49 \%$ think that a priori- tisation of hydropower on the distribution level might be a viable means to achieve environmental objectives, $50 \%$ express the opposite opinion. On closer inspection, however, it becomes obvious that the different political actors have very marked opinions on this issue. While $62 \%$ of the right-centre wing are opposing the prioritising of hydropower, $68 \%$ of the left-green wing is advocating it. Likewise, the alpine cantons, in which most of the hydropower resources are located, are in favour of the prioritising (67\% compared to $46 \%$ of the other cantons). This indicates a coalition potential between the social democrats and the traditionally conservatively governed alpine cantons, which had already taken effect in the debate on the rise of water interests during the revision of the water legislation in 1996. This is supported by the fact that, within the left-green wing, the advocacy for the prioritising of hydropower is particularly strong among the social democrats $(74 \%)$.

Another remarkable difference concerning the prioritising of hydropower occurs with respect to the cleavage of language: Along with the left-green wing and the alpine cantons, the French-speaking Swiss are plainly supporting the idea of prioritising $(74 \%$ compared to $42 \%$ of the Swiss Germans). How can this unequivocal statement in favour of hydropower be interpreted? On the one hand, there is a slight overrepresentation among French-speaking left-green wing exponents in our sample. On the other hand the nuclear power stations are all located in the German-speaking part of Switzerland, whereas some larger hydropower stations (including the ones with the highest stranded investments) are based in the French part, thus prioritising hydropower means defending regional interests.

As we have seen, the energy policy key players consider marketing as an efficient, but not sufficient instrument to promote renewable energy and their responses as to the prioritising of hydropower are equivocal. Another instrument that may contribute to the promotion of green electricity and also to the promotion of Swiss hydropower within the liberalised European electricity market is eco-labelling "clean" electricity. A number of labelling schemes have already evolved in liberalised electricity markets such as California, Pennsylvania, Sweden, and Australia, and a Swiss eco-label for electricity is about to be introduced this year. As they are usually a result of non-governmental initiatives, such labelling schemes are not literally instruments of energy policy regulation. If properly designed and managed, they can, however, cause substantial changes in the behaviour of consumers and electricity suppliers, and contribute to the achievement of environmental policy goals. This might be a strong incentive for a government to support such a labelling project, e.g. by educating consumers and supporting research on adequate environmental assessment criteria.

Summarising the results from the discussion of instruments for achieving environmental goals in the 
Table 5

Technology preferences regarding the future power generation mix $^{\mathrm{a}}$

\begin{tabular}{|c|c|c|c|c|c|c|c|c|c|c|}
\hline & Hydro & $\begin{array}{l}\text { Energy } \\
\text { efficiency }\end{array}$ & $\begin{array}{l}\text { Cogeneration } \\
(\mathrm{CHP})\end{array}$ & PV & Geothermal & $\begin{array}{l}\text { Combined } \\
\text { cycle (Gas) }\end{array}$ & Fuel cells & Wind & Import & Nuclear \\
\hline Absolutely & $72 \%$ & $70 \%$ & $40 \%$ & $34 \%$ & $31 \%$ & $20 \%$ & $31 \%$ & $17 \%$ & $11 \%$ & $16 \%$ \\
\hline Rather & $25 \%$ & $24 \%$ & $49 \%$ & $47 \%$ & $45 \%$ & $52 \%$ & $40 \%$ & $39 \%$ & $44 \%$ & $31 \%$ \\
\hline Rather not & $3 \%$ & $5 \%$ & $10 \%$ & $15 \%$ & $19 \%$ & $24 \%$ & $23 \%$ & $33 \%$ & $35 \%$ & $24 \%$ \\
\hline Not at all & $0 \%$ & $0 \%$ & $1 \%$ & $5 \%$ & $5 \%$ & $3 \%$ & $6 \%$ & $11 \%$ & $11 \%$ & $29 \%$ \\
\hline $\mathrm{N}$ & 232 & 230 & 228 & 228 & 224 & 211 & 190 & 229 & 226 & 229 \\
\hline
\end{tabular}

a"Should the respective option contribute to the future electricity supply?".

liberalised market, we see that the support for energy taxes may be growing, yet to a limited extent. The results of our survey reveal some ambiguities in the decisionmakers' views on this issue. For example, they consider market-based instruments such as taxes and ecological tax reforms, as the most environmentally efficient instruments when asked on an abstract level (i.e. independently of actually discussed bills), followed by subsidies as the second most efficient. At the same time, they give priority to the ecological criteria when asked for their preference among the criteria to evaluate energy policy instruments (ecological efficiency (1), influence on economic competition (2), aptitude to political execution (3), to political consensus (4), and to diffusion (5)). However, as soon as one passes from rhetoric to concrete action and from basic values to particular legislation, the picture changes significantly. The future will show whether this gap will be closed. Other solutions rated "first best" from an economic efficiency point of view and having been introduced in other countries, such as a system of emission certificates or tradable pollution permits, have not been subject to the policy discussion in Switzerland yet. Among the second best solutions, subsidies for renewables are generally acknowledged as being effective for the promotion of environmentally benign energy technologies. The idea of prioritising hydropower is more divergently assessed, and gets support from the left wing, the alpine cantons and the French-speaking part of Switzerland mainly.

\section{Long-term perspectives for the Swiss energy sector}

So far, we have been discussing instruments of reregulation in the Swiss electricity market, presently under debate. But what should the long-term structure of the electricity system (as an aim of energy policy) look like? To find out more about the ideas of the policy makers and thus the scope for consensual scenarios of the energy system, we have asked the political decision-makers to evaluate 10 different power generation technologies. The interviewed people indicated whether the respective technology should contribute to the future electricity supply.
We included likewise the options "importing electricity" and "increasing energy efficiency". The latter reflects that an increasing demand is not merely an exogenous trend but that it can be influenced by means like rising energy prices or implementing demand-side management (DSM) programmes. The former is rooted in the present supply structure: Switzerland has long-term supply contracts with French nuclear power plants, which have been signed in the aftermath of the nuclear moratorium we mentioned earlier and which, in part, have not even become effective yet. Unlike the policies of the 1970s and 1980s based on the principle of the countries' self-supply, a certain import dependency is nowadays being seen as a viable alternative to domestic generation. ${ }^{14}$

Table 5 gives an overview of the evaluation of the different options. All technologies were assessed positively by a majority with the exception of nuclear energy. It can be deduced that the policy makers advocate a balanced energy mix, based on a diversified portfolio of generation technologies. The percentage of the key players' nuclear disapproval corresponds fairly well to the average refusal by the population. ${ }^{15}$ Definitely supported are hydropower and energy efficiency, followed by cogeneration and $P V$. These results are inert to partisan, regional and language differences. Moreover, the new renewable energies are generally appreciated; wind

\footnotetext{
${ }^{14}$ Another aspect of imports is that Switzerland as a largely hydrobased electricity system is forced to balance the seasonal variation of its generation capacities by importing during winter and exporting in the summer. This temporary kind of import was, however, not meant when including the import option to the item.

${ }^{15}$ A look at the voting on nuclear issues since the 1970 s shows quite similar outcomes. In 1979, the popular initiative for "the protection of popular rights and a secure construction and operating of nuclear power plants" was rejected by $51 \%$; in 1984 the initiative for "a future without nuclear power plants" was rejected by $55 \%$; in $199053 \%$ opposed "the abandon of nuclear power". At the same time and in the aftermath of Tchernobyl, the initiative demanding a "10-year moratorium for nuclear issues" was accepted by $55 \%$ and has a considerable impact on Swiss nuclear policy since that time, i.e. impedes important decisions in the domain. Another popular initiative to phase out nuclear power is now in the political pipeline and the voting outcome is quite open (source: http://www.admin.ch/bfe).
} 
energy being the most controversial within this category, still supported by $56 \%$. As the total number of responses is somewhat lower for fuel cells, it can be supposed that this rather new technology is ignored by about a fifth of the interviewed policy makers, with the remaining strongly supporting it. The option of importing electricity does not find an unambiguous majority. As could be expected in the aftermath of the nuclear struggle in the 1980 s, our data reveal a nuclear gap, based on the classical left-right partisan cleavage. While $92 \%$ of the leftgreen wing are opposing nuclear power, $72 \%$ of the right-centre wing go on supporting it. Likewise, the language cleavage becomes visible in this question: $65 \%$ of the French Swiss prefer a future without nuclear energy (compared to $50 \%$ of the Swiss Germans). The alpine cantons - which are, as we have seen, in favour of hydropower - manifest their opposition against nuclear power $(60 \%)$.

As in the case of nuclear energy, the partisan cleavage takes effect relating to new renewable energies, which are definitely supported by the left and green exponents, but opposed by about a third of the right-centre actors. This gap becomes particularly visible with respect to wind energy, which is supported by $78 \%$ of the left-green wing, but opposed by $54 \%$ of the right-centre wing. Finally, the option of importing electricity mobilises as well around the partisan cleavage, i.e. $65 \%$ of the rightcentre would like to keep the import option open, whereas $67 \%$ of the left-green oppose imports as a viable long-term strategy.

Another question of the survey underlines the differences in the evaluation of future power generation options. We have asked whether the existing power plants should be renewed in a long-term view. The results reflect the preferences expressed above in an even more polarised manner (Table 6). Eighty-four per cent strongly support the idea of renewing existing hydropower stations, and literally no one opposes it. Obviously even those who are sceptical towards new hydropower capacities have come to terms with the existing facilities. The agreement on the renewal of hydroelectric power plants is homogeneous among parties, cantons and linguistic

Table 6

The long-term renewal of power plants ${ }^{\mathrm{a}}$

\begin{tabular}{lcc}
\hline & Hydro-power & Nuclear \\
\hline Absolutely & $84 \%$ & $26 \%$ \\
Rather & $16 \%$ & $24 \%$ \\
Rather not & $0 \%$ & $13 \%$ \\
Not at all & $0 \%$ & $37 \%$ \\
N & 231 & 225 \\
\hline
\end{tabular}

${ }^{a}$ Is the renewal of hydropower plants after the liberalisation important?". Is the renewal of nuclearpower plants after the liberalisation important?". regions. The issue of nuclear power polarises again. While $16 \%(29 \%)$ have stated that they are strongly in favour (against) nuclear as a part of the future electricity mix, the extreme positions increase to $26 \%(37 \%)$ as to the renewal of nuclear plants (or not) in the long run. Once more there is a strong division along the partisan cleavage $(92 \%$ of the left-green against, $76 \%$ of the rightcentre in favour), the cantons ( $60 \%$ of the alpine cantons against, $52 \%$ of the other cantons in favour) and the language cleavage $(60 \%$ of the French Swiss against, $53 \%$ of the German Swiss in favour).

It is interesting to note that there is a certain correlation between the support for nuclear energy and age of the respondents. From our data on nuclear energy, ${ }^{16}$ we can presume that nuclear enthusiasts are mainly among the elder generation: there is a caesura between the ageclasses of 1931-40 and older and the age-classes of 1941-50 and younger. The youngest interviewees express the strongest nuclear-critical opinions. This points out that the younger key players in energy policy grew up in a context where the nuclear technology and its risks were discussed in a more controversial way. The phenomenon of nuclear energy being supported mainly by older people has been found elsewhere, too. A market research study on behalf of the municipal utility of Zurich among 500 private households in the city of Zurich concludes that only $13 \%$ of the respondents think that nuclear power should be used in electricity generation (hydro $70 \%$, solar $50 \%$, wind $27 \%$, coal $0 \%$ ) (IPSO, 1996, p. 22 ). The authors noted that sex and age are strong variables influencing the acceptance of nuclear energy. While $20 \%$ of the men said, that electricity should be generated from nuclear energy, only $7 \%$ of the women were of the same opinion, and the younger respondents were significantly more critical than the older ones. Coming back to the key players that we interviewed, one might conclude that the present situation with about $50 \%$ of supporters and opponents of nuclear energy might change into a stronger rejection of the nuclear option with the (automatic) renewal of generation in politics. This sort of nuclear conflict resolution by way of generation change might, in turn, open opportunities for proactive strategies to substantially increase the use of renewables and energy efficiency. ${ }^{17}$

Summarising the results with regard to the long-term perspectives of the energy mix, the outcome of the survey is again somewhat ambiguous. On the one hand, an

\footnotetext{
${ }^{16}$ Question on the technological preference of future electricity supply (1), question on the long-term renewal of nuclear power plants (2), question on the reimbursement of stranded investment from nuclear power plants.

${ }^{17}$ There is of course another possible interpretation, which is that this situation changes over time, i.e. that the younger people's attitudes change towards less nuclear-critic positions as they are getting older.
} 
overwhelming majority supports a mix of hydropower, increased energy efficiency, and new renewables. As hydropower accounts for about $60 \%$ of the present Swiss power generation, as the potential for increasing energy efficiency is significant and as new renewables have hardly been developed up to now, the outline of a consensual and sustainable Swiss energy policy seems quite obvious: Phasing out nuclear power and designing an intelligent policy mix with economic incentives to replace $40 \%$ of the generation capacity by a combination of efficiency improvements and new renewables. The results from the ongoing polarisation on the nuclear issue suggest, however, that the strong minorities favouring this option may still cause considerable frictions on the political level in the years to come. This can also be seen in the German debate on the nuclear option where the redgreen majority faces severe difficulties in realising their objective of phasing out nuclear power. We can expect that the Swiss debate will be influenced by the outcome of the corresponding processes in Germany. Another influencing factor will be the extent to which the pro-nuclear groups succeed in linking their particular interests to the climate change debate and in avoiding full internalisation of risk costs for nuclear power generation.

\section{Conclusions}

In this paper, we discussed empirical insights from a survey among 250 key players in Swiss energy policy on the eve of market liberalisation, referring especially to their views on environmental issues and ecologically adequate instruments. It turns out that there is a general consensus that market liberalisation in itself will not result in the achievement of environmental goals, and that there is therefore a need for an adapted policy-mix to reach these goals. As for the first-best type of instruments recommended by economists - the internalisation of external costs by means of energy or emission taxes - there is an agreement on the general suitability of these market-based instruments. However, the survey data also reveal important resistance of strong minorities as soon as it comes to concrete approaches to implement such taxes. The resulting distortions in the policy process do presently, and will probably in the foreseeable future, hinder the introduction of effective eco-taxation. This points out a need for a bundle of second-best solutions that may include well-designed subsidies as well as green electricity marketing and eco-labelling in spite of the specific shortcomings of each of these instruments. As for the longer-term perspectives of the Swiss electricity system, a number of technologies are widely accepted in the opinion of the key players, including hydropower, energy efficiency, and new renewables to a large extent. If this corresponds to a similar assessment among the general public, these technologies might thus constitute the cornerstones of a sustainable and consensual energy mix. From the point of view of political consensus, a big question mark has to be put behind the future of nuclear energy, which still polarises supporters and opponents. The age structure of the nuclear protagonists and upcoming economic pressures in the liberalised market can be considered as weak indicators for future majority shifts. It is, however, a long way off from an opinion shift to the actual substitution of $40 \%$ of the power generation capacities. Such a profound structural change would require a leadership defending clear-cut goals and economic incentives with respect to sustainable development. But as in any structural change, today's losers are crying out louder than tomorrow's winners, and the kind of venturing political leaders seem to be rare in (Swiss) politics.

\section{References}

Birnbaum, P., 1973. Le pouvoir politique: de la décision du système. Revue Française de Sociologie 14, 336-351.

Dahl, R.A., 1961. Who Governs? Democracy and Power in an American City. Yale University Press, New Haven.

Drillisch, J., Riechmann, C., 1998. Liberalisation of the Electricity Supply Industry - Evaluation of Reform Policies. EWI Institute of Energy Economics at the University of Cologne.

IPSO, 1996. Bericht der repräsentativen EWZ-Kundenbefragung. Dübendorf.

Jegen, M., 1999. Akteure und energiepolitische Kernprobleme. Mémoire préliminaire déposé à l'Université de Genève.

Jegen, M., Kriesi, H., 1999. Instrumente zu einer nachhaltigen Schweizer Energiepolitik im Urteil energiepolitischer Schlüsselpersonen. Unpublished manuscript, University of Geneva.

Katzenstein, P., 1985. Small States in World Markets. Cornell University Press, Ithaca.

Kriesi, H., 1980. Entscheidungsstrukturen und Entscheidungsprozesse in der Schweizer Politik. Campus, Frankfurt.

Kriesi, H., 1999. La mise en œuvre d'une réforme fiscale écologique: comment peut-elle devenir majoritaire? Papier Présenté lors d'une Conférence du CUEPE, Genève, 11 mars 1999.

Mach, A., 1998. Quelles réponses politiques face à la globalisation et à la construction européenne? Illustration à partir de la révision de la loi sur les cartels. Swiss Political Science Review 4 (2), 25-49.

Sabatier, P.A., Jenkins-Smith, H.C., 1993. Policy Change and Learning. An Advocacy Coalition Approach. Westview Press, Boulder.

Scharpf, F., 1997. Games Real Actors Play. Actor-centred Institutionalism in Policy Research. Westview Press, Boulder, CO.

Schlegelmilch, K., 1998. Energy Taxation in the EU and some Member States: Looking for Opportunities Ahead. Institute for Climate, Environment and Energy, Wuppertal.

Vogel, S.K., 1998. Free Markets, More Rules. Regulatory Reforms in Industrialized Countries. Cornell University Press, Ithaca.

VSE, 1999. Erzeugung und Abgabe elektrischer Energie in der Schweiz. Bulletin SEV/VSE 4/99, 75-76.

Wüstenhagen, R., 1998. Green electricity in Switzerland. A mere eco-niche or the first step towards a sustainable energy market at large? In: International Association for Energy Economics (Eds.), Energy Markets: What's New? Conference Proceedings, Berlin, pp. 143-151.

Wüstenhagen, R., 2000. Jenseits der Öko-Nische in der Elektrizitätsbranche. In: Villiger, A., Wüstenhagen, R., Meyer, A. (Eds.), (2000) Jenseits der Öko-Nische. Birkhäuser, Basel/Boston/Berlin. 